REPRODUCING the FRENCH RACE 



\title{
REPRODUCING the FRENCH RACE
}

\section{I미}

\author{
Immigration, Intimacy, \\ and Embodiment in the \\ Early Twentieth Century
}

ELISA CAMISCIOLI

Duke University Press

Durham and London

2009 
(C) 2009 Duke University Press

All rights reserved.

Printed in the United States of America on acid-free paper @ Designed by Heather Hensley

Typeset in Monotype Fournier by Tseng Information Systems, Inc.

Library of Congress Cataloging-in-Publication Data appear on the last printed page of this book. 
For my parents, ELIZABETH AND THEODORE CAMISCIOLI 
